\title{
Mammal richness and diversity in Serra do Facão region, Southeastern Goiás state, central Brazil
}

\author{
Leonardo de Paula Gomes ${ }^{1,3}$, Clarisse Rezende Rocha ${ }^{2}$, Reuber Albuquerque Brandão ${ }^{1}$ \& \\ Jader Marinho-Filho ${ }^{2}$ \\ ${ }^{1}$ Universidade de Brasília, Faculdade de Tecnologia, Departamento de Engenharia Florestal, Brasília, DF, Brazil. \\ ${ }^{2}$ Universidade de Brasília, Instituto de Ciências Biológicas, Departamento de Zoologia, Brasília, DF, Brazil. \\ ${ }^{3}$ Corresponding author: Leonardo de Paula Gomes, e-mail: leonardop_gomes@yahoo.com.br
}

GOMES, L.P., ROCHA, C.R., BRANDÃO, R.A., MARINHO FILHO, J. Mammal richness and diversity in Serra do Facão region, Southeastern Goiás state, central Brazil. Biota Neotropica. 15(4): e0033. http://dx.doi.org/10.1590/1676-0611-BN-2015-0033

\begin{abstract}
At least 251 mammal species are recorded for the Brazilan cerrado, which, therefore, is the third richest Brazilian biome. Most mammal surveys in Brazilian cerrado result from studies performed opportunistically and in short time periods. The aims of the present study were (1) provide a checklist for the mammalian fauna based on a five-year sampling in Serra do Facão region, Southeastern Goiás state; (2) compare small non-flying mammals diversity in open and forest areas and (3) compare species diversity before and after the flood caused by a hydroelectric reservoir filling. The data was gathered in 19 sampling periods, from May 2008 to September 2013. We sampled open and forest habitats and captured non-flying small mammals with Sherman and Tomahawk live traps and pitfalls; bats were sampled with mist-nets; large mammals were recorded with camera traps, and by direct observations and track surveys in field. We found 20 species of small non-flying mammals, 10 species of bats and 33 species of larger mammals. Species diversity was greater for forest than open habitats, and was also greater before than after the complete reservoir filling. About $10 \%$ of the recorded species are included in the Brazilian official list of threatened species. The total richness represents $25 \%$ of all cerrado mammal fauna, highlighting the importance of this area for regional mammal fauna conservation.
\end{abstract}

Keywords: cerrado, mammal survey, non-flying mammals, bats, large mammals, hydroelectric reservoir.

GOMES, L.P., ROCHA, C.R., BRANDÃO, R.A., MARINHO FILHO, J. Riqueza e diversidade de mamíferos na Região da Serra do Facão, sudeste do estado de Goiás, Brasil central. Biota Neotropica. 15(4): e0033. http://dx.doi.org/10.1590/1676-0611-BN-2015-0033

Resumo: Há 251 espécies de mamíferos de ocorrência confirmada no cerrado, o terceiro bioma brasileiro em riqueza de espécies. A maioria dos inventários da mastofauna do cerrado é resultado de estudos oportunísticos, com curta duração. Os objetivos do presente estudo foram (1) inventariar a mastofauna durante cinco anos de amostragens na região do Aproveitamento Hidrelétrico da Serra do Facão, no sudeste do estado de Goiás; (2) Comparar a diversidade de pequenos mamíferos em áreas abertas e florestais e (3) comparar a diversidade da mastofauna antes e depois da inundação causada pelo enchimento do reservatório do empreendimento hidrelétrico. A coleta de dados foi realizada em 19 campanhas de amostragem, entre maio de 2008 e setembro de 2013. Os pequenos mamíferos não voadores foram amostrados com armadilhas Sherman e Tomahawk, e armadilhas de queda; morcegos foram amostrados com redes de neblina; e os mamíferos de maior porte foram amostrados com armadilhas-fotográficas, observações diretas e observações de vestígios. Foram registradas 20 espécies de pequenos mamíferos não-voadores, 10 espécies de morcegos e 33 de mamíferos de maior porte. A diversidade de pequenos mamíferos não voadores foi maior em ambientes florestais que em abertos, e foi também maior antes do que depois do enchimento do reservatório da hidroelétrica. Cerca de $10 \%$ das espécies registradas estão incluídas na lista oficial dos mamíferos ameaçados de extinção. O total de espécies representa $25 \%$ da fauna de mamíferos do cerrado, o que demonstra a importância da área para conservação da mastofauna regional.

Palavras-chave: cerrado, inventário, pequenos mamiferos não voadores, morcegos, mamiferos de grande porte, reservatório hidrelétrico.

\section{Introduction}

Currently, 701 species of mammals are known in Brazil (Paglia et al. 2012). The mammal richness reported for the cerrado varies from 227 (Carmignotto et al. 2012) to 251 species (Paglia et al. 2012). About $40 \%$ cerrado mammals are bats (Chiroptera), 31\% are rodents (Rodentia), and 10\% are marsupials (Didelphimorphia) (Paglia et al. 2012). This diversity 
places the cerrado biome as the third richest for Brazilian mammals. The number of endemic cerrado mammals varies from 25 to 32 species depending on the authors (Carmignotto et al. 2012, Paglia et al. 2012). The distribution of mammal fauna in cerrado is affected by habitat heterogeneity, being approximately $16 \%$ of species exclusive to open areas, and about $29 \%$ occur exclusively in forest environments (Marinho-Filho et al. 2002). However, the endemism rate is slightly larger for open areas $(56 \%)$, highlighting the relevance of both open and forested habitats for cerrado mammals conservation (Marinho-Filho et al. 2002).

The original cerrado covered approximately 2 million $\mathrm{km}^{2}$. However, about half of its area was already removed by human activities, and the actual deforestation persist at rates varies between 22,000 to $30,000 \mathrm{~km}^{2} /$ year (Klink \& Machado 2005). Processes of habitat loss and fragmentation, as well as hunting pressure, are among the main threats to mammalian diversity conservation (Rodrigues et al. 2002, Costa et al. 2005, Trolle et al. 2007). Changes in the environment occur in an accelerated rate, causing loss of irreplaceable habitats at local and regional scale, and even resulting in local extinctions (Whitmore \& Sayer 1992, Myers et al. 2000).

In this context, inventories are essential because they provide basic information on biological diversity composition of determined areas and regions, providing arguments and justification for the conservation of remnant areas. However, the majority of fauna surveys on cerrado's mammalian fauna are performed punctually and in short time periods.

Herein we present a mammalian inventory based on five years sampling an area affected by the flooding of the reservoir of Serra do Facão Hydroelectric Plant, in southeastern Goiás state. Other aims of this study are to evaluate differences in richness and diversity for small non-flying mammals between (1) environments (open areas and forests) and (2) sampling periods (before and after the hydroelectric plant construction). We also provide reproductive ecological observations for small non-flying mammals.

\section{Material and Methods}

\section{Area of study}

The study was carried out in Serra do Facão region, southeastern Goiás state (Figure 1). The Serra do Facão region is crossed by São Marcos River, which belongs to Rio de la Plata Basin, the second largest river basin in South America (ANA 2007). In November 2009, a dam on the São Marcos River was built to form the reservoir of the hydroelectric plant of Serra do Facão. This reservoir floods ca. 20,000 ha, encompassing five municipalities in the state of Goiás: Catalão, Campo Alegre de Goiás, Davinópolis, Ipameri, and Cristalina - and the municipality of Paracatu, in the state of Minas Gerais.

In the region the climate is tropical (Köppen Aw), with temperatures between 23 and $24^{\circ} \mathrm{C}$ and mean annual rainfall between 1600 and $1800 \mathrm{~mm}$, and two well-defined seasons, one hot and rainy (October to Match) and other colder and dry (April to September) (Cardoso et al. 2015). The landscape consists of large tracts of plantation areas and pastures, in which there is a mosaic of remnant patches of native habitats,

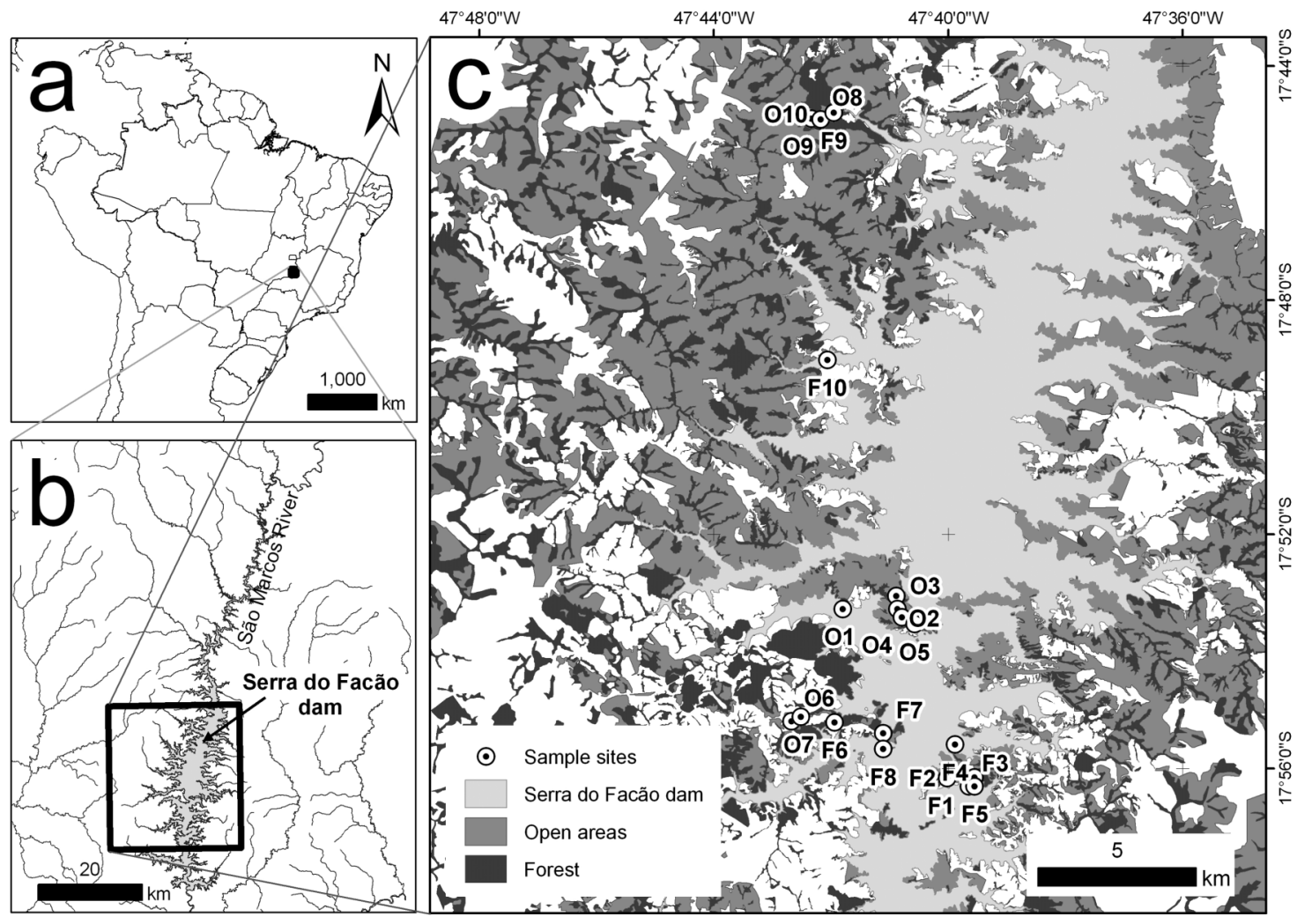

Figure 1. Serra do Facão state of Goiás, and location of sample sites a) Brazil; b) River system in the area; c) Sample Sites. O - Open areas; F - Forest. Description of sampling points and coordinates are on Supplement 1. 
including several open cerrado physiognomies as campo limpo, campo sujo, vereda (palm swamps), and "cerrado sensu stricto", and forest habitats, such as semi-deciduous forest, mata ciliar (riparian forest), and gallery forest. Phytophysiognomies were identified according to Oliveira-Filho \& Ratter (2002). Grassland without shrubs or trees is called campo limpo, and grassland with scattered shrubs and small trees is called campo sujo. Open cerrado physiognomies over rock soil and scattered rock outcrops - cerrado rupestre (Lenza et al. 2011) was present in some places. The cerrado sensu stricto have trees covering more than $30 \%$ of canopy, and presents an herbaceous/grassy layer. Veredas are valley marshes where the water table reaches the surface and palms Mauritia flexuosa are common. Semideciduous forest (mesophytic seasonal forest) generally grow on spots of calcareous fertile soils; gallery forests are placed along river banks, and the tree branches cover the water course, forming a "gallery". Riparian forests are also placed along river banks, but the water course is not covered by trees. The sampling sites included both open areas (grassland and "cerrado sensu stricto") and forest habitats (gallery forest and semi-deciduous forest).

\section{Data Collection}

We collected data on 19 field expeditions, with quarterly intervals, from May 2008 to February 2012. In 2013, we done three complementary expeditions in March, June and September. Initially, we gathered data in 10 sampling sites placed in open areas and 10 sampling sites placed in forest habitats (Figure 1, Supplement 1). However, after the impoundment in 2009, three forest sites were flooded. The study was carried out in areas located in the municipalities of Catalão and Campo Alegre de Goiás, state of Goiás (Supplement 1).

We considered small mammals all species of small rodents and marsupials with less than $2 \mathrm{~kg}$ (e.g. Bennett 1990, Eisenberg \& Redford 1999). This group was sampled using Sherman and Tomahawk traps, and some additional data came from pitfall traps. In every sample sites (Supplement 2), we set up 21 Sherman traps $(250 \times 80 \times 90 \mathrm{~mm})$ and seven Tomahawk traps $(300 \times 160 \times 160 \mathrm{~mm})$, which remained open during three consecutive nights in each field expedition. Traps were placed on soil level and on trees and shrubs, up to $2 \mathrm{~m}$ high as well, in order to access the greatest number of micro-habitats. Baits consisted of a mixture of peanut butter, banana, canned sardines and cornmeal. All traps were monitored every day at dawn. The sampling effort was 31,496 traps*night.

Pitfall traps consisted by stations composed by four 35-litre plastic buckets arranged in a Y-shaped disposition. All buckets were buried in the ground, placed $4 \mathrm{~m}$ away from each other, and connected by a plastic fence $(0.5 \mathrm{~m}$ height). Five pitfall trap stations were set at each sample site (Supplement 2). Pitfall traps were kept open for ten consecutive days in each expedition. Although pitfall traps are commonly used for herpetological sampling, they often capture small terrestrial mammals (Mengak \& Guynn Jr 1987, Santos Filho et al. 2008), being able to sample species that are rarely captured by more traditional methods (Monteiro-Filho \& Graipel 2006, Cáceres et al. 2010). During sampling periods all traps were checked every day and we performed a total sampling effort of 49,600 pitfalls*night.

Bats were recorded only in forest environments (Supplement 2). We used five to ten mist-nets (12 m length $\times 3 \mathrm{~m}$ height) in each sampling site, for a few nights (usually 1-2) per field expedition. The nets were set on forest edges, or inside them, near food sources and shelters, and/or on trails potentially used as flight route. Nets were opened at 18:00 $\mathrm{h}$ and closed at midnight. The total bat sampling effort, following Straube \& Bianconi (2002), was of 18,144 hours* ${ }^{2}$.

We identified, measured, and weighted all animals captured. We also recorded the reproductive status of all animals. We considered as reproductive all perforated, lactating, or pregnant females. Small non-flying mammals were marked with numbered earrings (National Band \& Tags - Mod. 1005 - 1). After data collection, we released all animals at the same place they were captured. Some specimens were collected for further confirmation of identification. All collected animals were deposited in the Mammal Collection of the University of Brasília (Supplement 3). All procedures (capture, handling and marking) followed the guidelines of animal care and use by the American Society of Mammalogists (Sikes \& Gannon 2011). All captures and collections were made upon authorization issued by the Brazilian Institute for the Environment (IBAMA ACCTMB No. 198/2010). We used the specific literature for taxonomic identifications (Vizotto \& Taddei 1973, Emmons \& Feer 1997, Weksler \& Bonvicino 2005, Carmignotto \& Monfort 2006, Bonvicino et al. 2008, Gardner 2008, Reis et al. 2013). Confirmation of the identifications were done by comparison with material (skins and skulls) housed in the mammal collections of the Zoology Department of the Universidade de Brasília and the Museu Nacional da Universidade Federal do Rio de Janeiro.

We sampled larger mammals opportunistically by tracking them while collecting or setting traps for small mammals sampling. Additionally we set a total of six to ten camera traps (Tigrinus Analog 6.0C), at some sampling site per expedition (Supplement 2). Camera traps were set in open and forest areas, and remained in operation for about ten consecutive days in each expedition. Some were set in trails, others not, but in any case they were set apart at least $1.5 \mathrm{~km}$ from each other. In 2013 we changed all camera traps by another digital model (Bushnell Trophy Cam HD). We also took into account direct sights, animals hit by cars and/or carcasses found, as well as indirect observations, such as tracks and feces, obtained during active diurnal and nightly surveys. The total effort performed with camera traps was 14,508 traps*hours. We did not consider photos of the same species taken in less than one hour interval for abundance counting. All species, including carcasses, tracks, and photos were identified using pertinent literature (Becker \& Dalponte 1991, Oliveira \& Cassaro 1999, Borges \& Tomás 2004, Mamede \& Alho 2006, Carvalho Jr \& Luz 2008, De Angelo et al. 2008).

\section{Data Analysis}

We used collector's curve based on effort by expedition for checking the reliability of our mammal survey, including all species obtained by all methods. For the analysis of diversity we used the number of individuals and not total captures of small mammals. We used rarefaction curves based on abundance for compare non-flying small mammal diversity between (1) open and forest areas, (2) before and after the reservoir filling in open areas, and (3) before and after flooding in forest habitats. All comparisons were done using Coleman index on EstimateS Version 9.1.0 (Colwell 2013) and tested differences using $Z$ tests (Zar 1999). 
Gomes, L.P. et al.

Table 1. Mammalian species recorded at Serra do Facão region from 2008 to 2013. Families richness is displayed at parenthesis. Habitat of record and sampling methods are: $\mathrm{O}=$ open areas, $\mathrm{F}=$ forest, $\mathrm{Cap}=$ capture, $\mathrm{Vs}=$ visually, $\mathrm{Ct}=$ camera trap, $\mathrm{Ts}=$ track surveys.

\begin{tabular}{|c|c|c|}
\hline Taxa & Habitat & Sampling method \\
\hline \multicolumn{3}{|l|}{ DIDELPHIMORPHIA } \\
\hline Caluromys lanatus (Olfers, 1818) & $\mathrm{F}$ & Cap \\
\hline Cryptonanus agricolai (Moojen, 1943) & $\mathrm{O}$ & Cap \\
\hline Didelphis albiventris Lund, 1840 & $\mathrm{O}, \mathrm{F}$ & Cap \\
\hline Gracilinanus agilis (Burmeister, 1854) & $\mathrm{O}, \mathrm{F}$ & Cap \\
\hline Micoureus demerarae (Thomas, 1905) & $\mathrm{F}$ & Cap \\
\hline Monodelphis domestica (Wagner, 1842) & $\mathrm{O}, \mathrm{F}$ & Cap \\
\hline Monodelphis kunsi Pine, 1975 & $\mathrm{O}, \mathrm{F}$ & Cap \\
\hline Thylamys karimii (Petter, 1968) & $\mathrm{O}$ & Cap \\
\hline \multicolumn{3}{|l|}{ CINGULATA } \\
\hline \multicolumn{3}{|l|}{ Dasypodidae (5) } \\
\hline Cabassous unicinctus (Linnaeus, 1758) & $\mathrm{O}$ & Vs \\
\hline Dasypus novemcinctus Linnaeus, 1758 & $\mathrm{~F}$ & $\mathrm{Ct}$ \\
\hline Dasypus septemcinctus Linnaeus, 1758 & $\mathrm{~F}$ & Vs \\
\hline Euphractus sexcinctus (Linnaeus, 1758) & $\mathrm{O}$ & Vs \\
\hline Priodontes maximus (Kerr, 1792)* & $\mathrm{F}$ & $\mathrm{Ct}, \mathrm{Vs}$, Ts \\
\hline \multicolumn{3}{|l|}{ PILOSA } \\
\hline \multicolumn{3}{|l|}{ Myrmecophagidae (2) } \\
\hline Myrmecophaga tridactyla Linnaeus, $1758^{*}$ & $\mathrm{~F}, \mathrm{O}$ & $\mathrm{Ct}, \mathrm{Ts}, \mathrm{Vs}$ \\
\hline Tamandua tetradactyla (Linnaeus, 1758) & $\mathrm{F}$ & $\mathrm{Ct}, \mathrm{Ts}$ \\
\hline \multicolumn{3}{|l|}{ CHIROPTERA } \\
\hline \multicolumn{3}{|l|}{ Phyllostomidae (10) } \\
\hline Anoura caudifer (E. Geoffroy, 1818) & $\mathrm{F}$ & Cap \\
\hline Artibeus lituratus (Olfers, 1818) & $\mathrm{F}$ & Cap \\
\hline Carollia perspicillata (Linnaeus, 1758) & $\mathrm{F}$ & Cap \\
\hline Dermanura cinerea (Gervais 1855) & $\mathrm{F}$ & Cap \\
\hline Desmodus rotundus (E. Geoffroy, 1810) & $\mathrm{F}$ & Cap \\
\hline Glossophaga soricina (Pallas, 1766) & $\mathrm{F}$ & Cap \\
\hline Mimon bennettii (Gray, 1838) & $\mathrm{F}$ & Cap \\
\hline Phyllostomus hastatus (Pallas, 1767) & $\mathrm{F}$ & Cap \\
\hline Platyrrhinus lineatus (E. Geoffroy, 1810) & $\mathrm{F}$ & Cap \\
\hline Sturnira lilium (E. Geoffroy, 1810) & $\mathrm{F}$ & Cap \\
\hline \multicolumn{3}{|l|}{ PRIMATES } \\
\hline \multicolumn{3}{|l|}{ Atelidae (1) } \\
\hline Alouatta caraya (Humboldt, 1812) & $\mathrm{F}$ & Vs \\
\hline \multicolumn{3}{|l|}{ Callithrichidae (1) } \\
\hline Callithrix penicillata (E. Geoffroy, 1812) & $\mathrm{F}$ & Vs \\
\hline \multicolumn{3}{|l|}{ Cebidae (1) } \\
\hline Sapajus libidinosus (Spix, 1823) & $\mathrm{F}$ & $\mathrm{Ct}, \mathrm{Vs}$, Cap \\
\hline \multicolumn{3}{|l|}{ CARNIVORA } \\
\hline \multicolumn{3}{|l|}{ Canidae (3) } \\
\hline Cerdocyon thous (Linnaeus, 1766) & $\mathrm{O}$ & $\mathrm{Ct}, \mathrm{Vs}$, Cap \\
\hline Chrysocyon brachyurus (Illiger, 1815)* & $\mathrm{O}$ & $\mathrm{Ct}, \mathrm{Vs}$ \\
\hline Lycalopex vetulus (Lund, 1842)* & $\mathrm{O}$ & $\mathrm{Ct}, \mathrm{Vs}$ \\
\hline \multicolumn{3}{|l|}{ Procyonidae (2) } \\
\hline Nasua nasua (Linnaeus, 1766) & $\mathrm{F}, \mathrm{O}$ & $\mathrm{Ct}, \mathrm{Vs}$, Cap \\
\hline Procyon cancrivorus (G. Cuvier, 1798) & $\mathrm{F}, \mathrm{O}$ & $\mathrm{Ct}, \mathrm{Vs}$ \\
\hline \multicolumn{3}{|l|}{ Mustelidae (4) } \\
\hline Conepatus semistriatus (Boddaert, 1785) & $\mathrm{O}$ & Vs \\
\hline Eira barbara (Linnaeus, 1758) & $\mathrm{F}$ & $\mathrm{Ct}, \mathrm{Vs}$ \\
\hline Galictis cuja (Molina, 1782) & $\mathrm{O}, \mathrm{F}$ & Vs \\
\hline Lontra longicaudis (Olfers, 1818) & $\mathrm{F}$ & Vs, Ts \\
\hline \multicolumn{3}{|l|}{ Felidae (5) } \\
\hline Leopardus pardalis (Linnaeus, 1758) & $\mathrm{F}$ & $\mathrm{Ct}$, Cap, Ts \\
\hline Leopardus tigrinus (Schreber, 1775)* & $\mathrm{F}$ & Ts, Vs \\
\hline
\end{tabular}


Table 1. Continued.

\begin{tabular}{|c|c|c|}
\hline Taxa & Habitat & Sampling method \\
\hline Leopardus wiedii (Schinz, 1821)* & $\mathrm{F}$ & $\mathrm{Ct}$ \\
\hline Puma concolor (Linnaeus, 1771)* & $\mathrm{F}$ & $\mathrm{Ct}$, Ts \\
\hline Puma yagouaroundi (E. Geoffroy, 1803)* & $\mathrm{F}$ & Vs \\
\hline \multicolumn{3}{|l|}{ PERISSODACTYLA } \\
\hline \multicolumn{3}{|l|}{ Tapiridae (1) } \\
\hline Tapirus terrestris (Linnaeus, 1758) & $\mathrm{F}, \mathrm{O}$ & Ts \\
\hline \multicolumn{3}{|l|}{ ARTIODACTYLA } \\
\hline \multicolumn{3}{|l|}{ Tayassuidae (1) } \\
\hline Pecari tajacu (Linnaeus, 1758) & $\mathrm{F}$ & $\mathrm{Ct}$, Vs, Ts \\
\hline \multicolumn{3}{|l|}{ Cervidae (2) } \\
\hline Mazama americana (Erxleben, 1777) & $\mathrm{F}$ & $\mathrm{Ct}, \mathrm{Vs}$ \\
\hline Mazama gouazoubira (G. Fischer, 1814) & $\mathrm{O}, \mathrm{F}$ & $\mathrm{Ct}, \mathrm{Vs}$ \\
\hline \multicolumn{3}{|l|}{ RODENTIA } \\
\hline \multicolumn{3}{|l|}{ Cricetidae (10) } \\
\hline Calomys expulsus (Lund, 1841) & $\mathrm{O}, \mathrm{F}$ & Cap \\
\hline Calomys tener (Winge, 1887) & $\mathrm{O}, \mathrm{F}$ & Cap \\
\hline Cerradomys scotti (Langguth \& Bonvicino, 2002) & $\mathrm{O}, \mathrm{F}$ & Cap \\
\hline Hylaeamys megacephalus (G. Fischer, 1814) & $\mathrm{O}, \mathrm{F}$ & Cap \\
\hline Necromys lasiurus (Lund, 1841) & $\mathrm{O}$ & Cap \\
\hline Oecomys cleberi Locks 1981 & $\mathrm{~F}$ & Cap \\
\hline Oligoryzomys fornesi (Massoia, 1973) & $\mathrm{F}$ & \\
\hline Oligoryzomys moojeni Weksler \& Bonvicino 2005 & $\mathrm{~F}$ & Cap \\
\hline Oligoryzomys nigripes (Olfers, 1818) & $\mathrm{O}, \mathrm{F}$ & Cap \\
\hline Rhipidomys macrurus (Gervais, 1855) & $\mathrm{O}, \mathrm{F}$ & Cap \\
\hline \multicolumn{3}{|l|}{ Erethizontidae (1) } \\
\hline Coendou prehensilis (Linnaeus, 1758) & $\mathrm{F}$ & Vs \\
\hline \multicolumn{3}{|l|}{ Caviidae (1) } \\
\hline Hydrochoerus hydrochaeris & $\mathrm{F}$ & Ts \\
\hline \multicolumn{3}{|l|}{ Cuniculidae (1) } \\
\hline Cuniculus paca (Linnaeus, 1766) & $\mathrm{F}$ & $\mathrm{Ct}$ \\
\hline \multicolumn{3}{|l|}{ Dasyproctidae (1) } \\
\hline Dasyprocta azarae Lichtenstein, 1823 & $\mathrm{~F}$ & Vs \\
\hline \multicolumn{3}{|l|}{ Echimyidae (2) } \\
\hline Proechimys roberti Thomas, 1901 & $\mathrm{~F}$ & Cap \\
\hline Thrichomys apereoides (Lund, 1839) & $\mathrm{O}$ & Cap \\
\hline \multicolumn{3}{|l|}{ LAGOMORPHA } \\
\hline \multicolumn{3}{|l|}{ Leporidae (1) } \\
\hline Sylvilagus brasiliensis (Linnaeus, 1758) & $\mathrm{F}$ & $\mathrm{Ct}, \mathrm{Vs}$ \\
\hline
\end{tabular}

* Threatened species (MMA 2014).

Reproductive patterns were roughly designed by the percentage of reproductive females in dry and wet seasons. Our sampling of larger mammals with camera traps did not allow the recognition of individuals and abundance estimates. However the number of records may provide an idea of abundance or activity of a given species in the area or specific habitat type.

\section{Results}

We recorded 63 species of mammals in the study area: 33 larger mammals, 20 small non-flying mammals and 10 bats (all belonging to the Phyllostomidae family) (Table 1). The collector's curve based on sampling effort by expedition for all species stabilized on the $13^{\text {th }}$ expedition (Figure 2), indicating we performed an adequate effort to sample the local richness. We recorded eight species considered as threatened with extinction (MMA 2014), such as Puma concolor and Priodontes maximus (Table 1).
The sampling effort with camera traps was equivalent to 14,508 traps*hour, which yielded 231 records of 22 species of large mammals. Photographic records of some species are presented on Supplement 4. Data from direct and indirect observations resulted in 11 additional species that were not recorded by camera traps, totaling 33 species of large mammals observed with all thechniques combined. The most speciose large mammals families were Dasypodidae $(n=5)$ and Felidae $(n=5)$. More than half large species $(51 \%)$ were recorded exclusively in forest environments, $24.5 \%$ were recorded only in open areas and $24.5 \%$ in both environments. The species with greater number of records were Mymercophaga tridactyla $(\mathrm{n}=54)$ and Sylvilagus brasiliensis $(\mathrm{n}=30)$. The smallest number of records were obtained for Lycalopex vetulus $(\mathrm{n}=4)$ and Mazama americana $(\mathrm{n}=2)$.

The sampling effort of 18,144 hour* $^{2}$ with mist nets in forest habitats resulted in capture of 107 individuals of 10 species of bats. The most frequently captured bat species were Carollia perspicillata $(\mathrm{n}=26)$ and Artibeus lituratus (19), and 


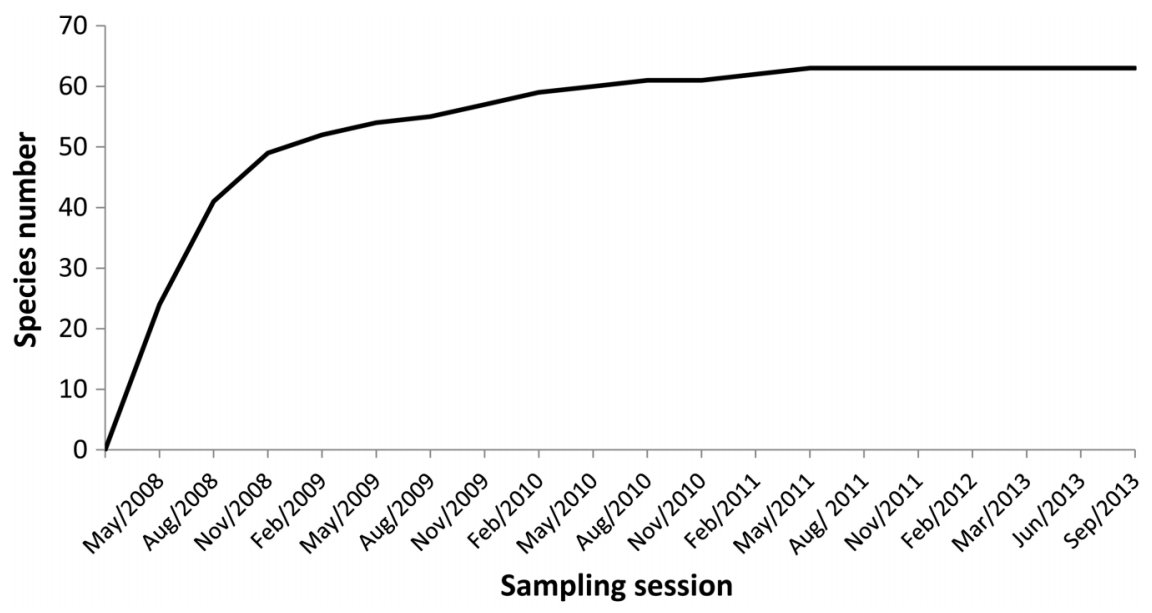

Figure 2. Species accumulation curve (collector's curve) based on effort for all mammalian species recorded in the Serra do Facão hydroelectric plant from May 2008 to September 2013.

Mimon benetti was recorded only once. For small non-flying mammals, the capture success with live traps (Sherman and Tomahawk) was approximately $2 \%$, with 20 species recorded. Pitfall traps did not resulted in exclusive additional records of species. However, two species of rodents $(O$. cleberi and $P$. roberti), and two species of marsupials ( $C$. lanatus and $M$. demararae) were recorded exclusively with live traps.

The Cricetidae family was the most representative, with 10 species, followed by Didelphidae $(n=8)$. Five species were captured only in forest environments, three of them were restricted to open areas, and eleven were captured in both environments. Gracilinanus agilis was the most frequently captured small mammal $(\mathrm{N}=255)$, followed by Calomys tener $(\mathrm{N}=200)$. These two species were more abundant in dry season (C. tener $-\mathrm{n}=141$ e G. agilis $-\mathrm{n}=209)$. Marsupials were reproductive during wet season, whereas rodents were reproductive during all year (Figure 3). About $24 \%$ of all G. agilis females captured on wet season were reproductive, whereas only $4 \%$ of them were reproductive during all dry season. The species $C$. tener was found reproductive throughout the year (Figure 3). The rodents Oecomys cleberi, Proechymys roberti, and Rhipidomys macrurus and the marsupials Caluromys lanatus and Thylamys karimii were the rarest small mammal species, with only one to three records each. Since field expeditions, we used this group to assess local populational and diversity parameters.

Forest habitats were more diverse in small terrestrial mammals than open areas $(Z=-8.115 ; p<0.001$; Figure 4$)$. The diversity was higher before flooding for both open $(Z=-8.956$; $\mathrm{p}<0.001 ;$ Figure 5) and forest habitats $(Z=-2.530 ; \mathrm{p}=0.005$; Figure 6)

\section{Discussion}

We found mammal richness similar to those reported in long sampling period studies conducted in cerrado Protected Areas (Table 2). Despite our larger sampling effort, we recorded $73 \%$ of mammals recorded for Emas National Park,

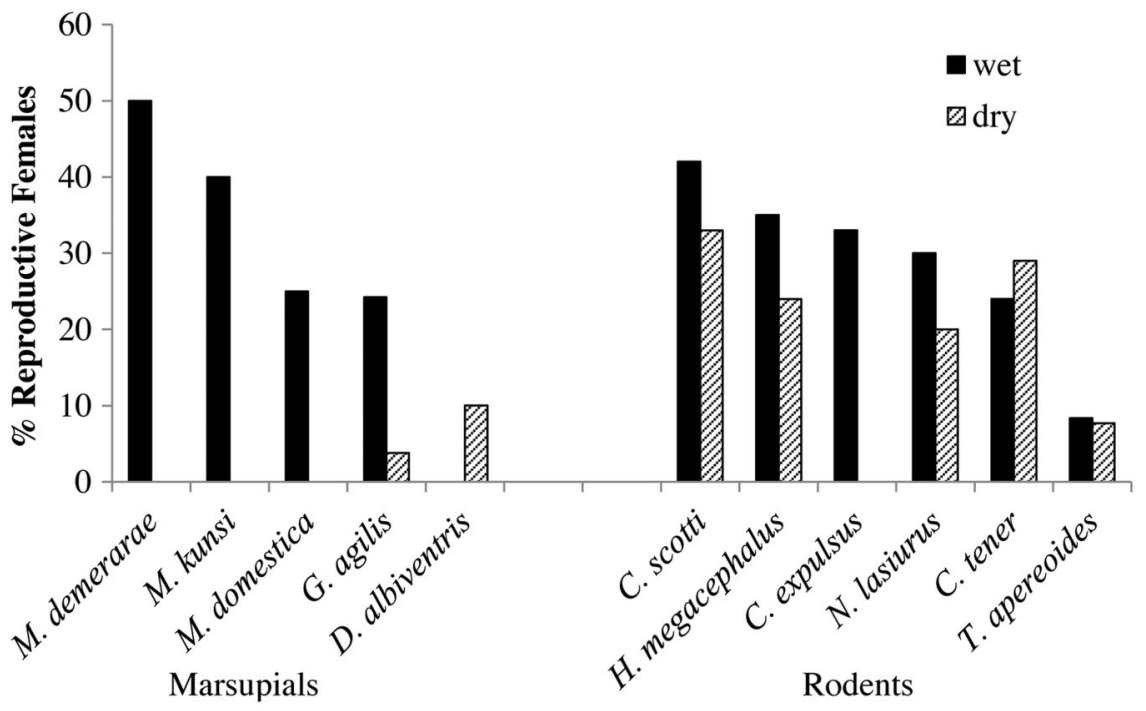

Figure 3. Percentage of reproductive females of marsupials and rodents captured during dry and wet seasons at Serra do Facão region, Goiás state, from May 2008 to September 2013. 


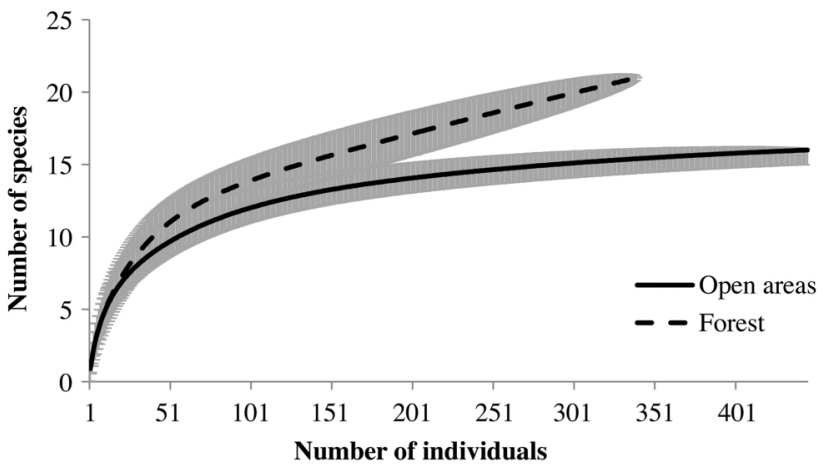

Figure 4. Rarefaction curves (Cole estimator) for small non-volant mammals captured in open and forest environments at Serra do Facão, Goiás state, from May 2008 to September 2013.

with about 132,000 ha (Rodrigues et al. 2002). Águas Emendadas Ecological Station, in the Federal District, with 11,000 ha, shows similar species richness (Marinho-Filho et al. 1998 ) to Serra do Facão region. Other studies found between 24 and 93 species for areas of different sizes and locations in the Brazilian cerrado (Mares et al. 1989, Schneider 2000, Moreira et al. 2008, Pereira \& Geise 2009) (Table 2).

Small Mammals - We recorded 20 species of small nonflying mammals. About $25 \%$ of them were exclusive to forest environments and $15 \%$ were recorded only in open areas. This pattern is expected for the cerrado biome (Marinho-Filho et al. 2002). Considering studies in Protected Areas of cerrado and those that make use of pitfalls in addition to conventional traps, the richness of small non-flying mammals ranged from 19 to 29 species (Schneider 2000, Marinho-Filho et al. 2002, Pereira \& Geise 2009, Carmignotto \& Aires 2011, Bonvicino et al. 2012). This richness is similar (or even large) than our study, despite our larger sample effort (Table 2). The region of Serra do Facão has been greatly altered by human activity over the last 300 years, and now is also impacted by the fragmentation and reduction of natural habitats imposed by São Marcos river dams and by the infrastructure projects associated to Serra do Facão Hydroelectric Plant (Chaul 1997). However, the richness observed in the region of Serra do Facão is comparable to some Protected Areas in the cerrado domain, and other cerrado localities. We recorded some cerrado rare species (Marinho-Filho et al. 2002) as Oecomys cleberi, Micoureus

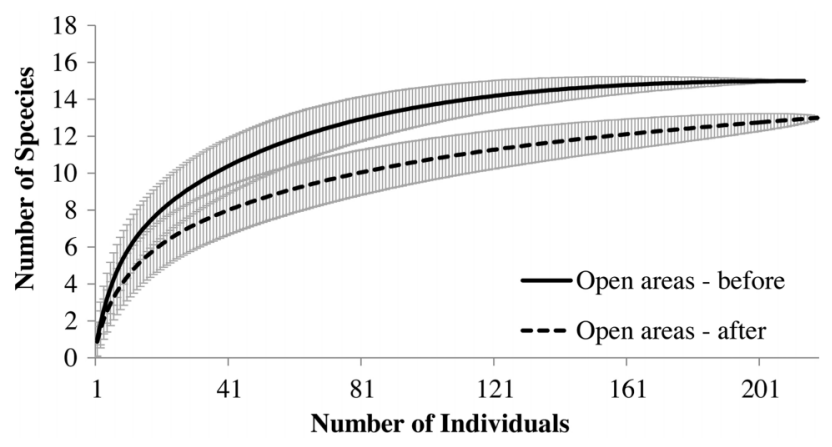

Figure 5. Rarefaction curves for small non-volant mammals in open areas before (May 2008 to November 2009) and after (February 2010 to September 2013) the reservoir flooding of the Hydroeletric Power Plant of Serra do Facão.

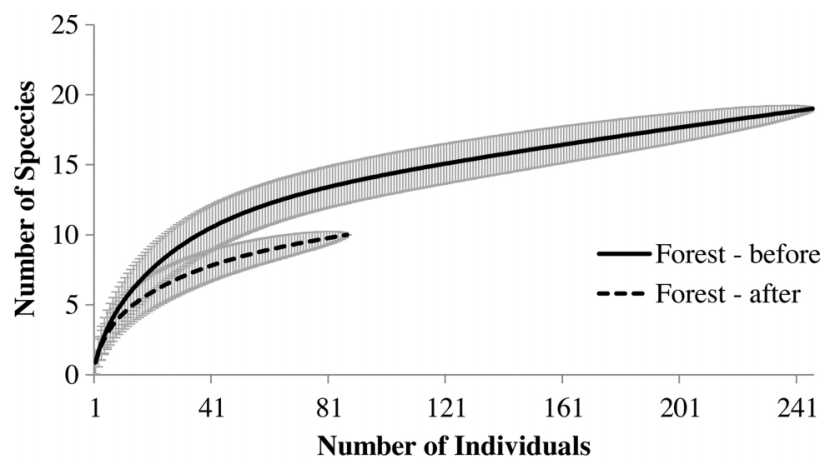

Figure 6. Rarefaction curves for small non-volant mammals in forest enviroments before (May 2008 to November 2009) and after (February 2010 to September 2013) the reservoir flooding of the Hydroeletric Power Plant of Serra do Facão.

demerarae, Caluromys lanatus, and Thylamys karimii, and their records were also rare throughout the study. The higher richness of forests when compared to open areas are also an expected finding for cerrado small non-flying mastofauna (Marinho-Filho et al. 2002).

The reservoir formation for the hydroelectric enterprise on Serra do Facão seemingly affected the small mammal diversity in open and forest habitats. The impacts of hydroelectric power plants on mammal communities were investigated by several other studies, and species loss is a common effect of reservoir filling (Cosson et al. 1999, Fournier-Chambrillon et al. 2000, Alho 2011, Andriolo et al. 2013). Besides habitat (and area) loss, the increase of predation and competition intensity are possible as factors affecting small non-flying mammals diversity loss in this kind of environmental change (Lemos de Sá 1995, Alho 2011, Andriolo et al. 2013, Passamani \& Cerboncini 2013).

Marsupials presented seasonal reproduction, whereas rodents were reproductive year round (Figure 3). The marsupial Gracilinanus agilis showed marked seasonal reproduction, confirming previous studies (Mares et al. 1989, Mares \& Ernest 1995 ) but the rodent Calomys tener, was reproductive in both rainy and dry seasons (Figure 3). Studies carried out in central cerrado showed that the reproduction in $C$. tener females is significantly greater during the rainy season, with reproductive individuals recorded year round, but in lower proportions during the dry season (Mares et al. 1989, Rocha 2011).

Bats - Bat richness in Serra do Facão is lower when compared to other areas in cerrado, which presented a richness ranging from 16 to 25 species (Marinho-Filho et al. 1998, Aguiar 2000, Rodrigues et al. 2002, Bezerra \& Marinho-Filho 2010). We recorded 10 species of bats, which represents only $10 \%$ of the richness known to the cerrado (Paglia et al. 2012). Although some other studies report equally modest numbers of bat species found in some cerrado areas (see Table 2 e.g. (Moreira et al. 2008) such low richness seems to be more an effect of relatively small sampling effort. The fact that we also only captured phyllostomid bats is expected with mist nets. The bat community from Serra do Facão is clearly undestimated and more species will be added with further sampling. However, there are some interesting records such as an individual of Mimon benetti a gleaning animalivore, not so common in inventories and collections. Although Anoura caudifer presents a wide distribution in South America, 
Gomes, L.P. et al.

Table 2. Mammalian richness from different Cerrado localities, including Protected Areas (PA).

\begin{tabular}{|c|c|c|c|c|c|}
\hline Richness & PA & Methodology & Year & Sampling effort & References \\
\hline \multicolumn{6}{|c|}{ Small non-flying mammals } \\
\hline 18 & yes & Sherman/Wire traps & 1986-1998 & not available & Marinho-Filho et al. 1998 \\
\hline 19 & yes & $\begin{array}{l}\text { Sherman/Wire traps } \\
\text { Pitfall }\end{array}$ & $2002-2004$ & $\begin{array}{l}\text { 10,897 traps*night } \\
\text { 2,671 pifalls*night }\end{array}$ & Pereira \& Geise 2009 \\
\hline 19 & no & Sherman/Wire traps & $1998 ; 1999 ; 2010$ & 7,651 traps*night & Bonvicino et al. 2012 \\
\hline 20 & no & $\begin{array}{l}\text { Sherman/Wire traps } \\
\text { Pitfall }\end{array}$ & 2008-2013 & $\begin{array}{l}31,496 \text { traps*night } \\
49,600 \text { pitfalls*night }\end{array}$ & This study \\
\hline 21 & yes & Sherman/Wire traps & $1999-2000$ & 13,200 traps*night & Santos-Filho et al. 2012 \\
\hline 23 & yes & $\begin{array}{l}\text { Sherman/Wire traps } \\
\text { Pitfall }\end{array}$ & 1998-1999 & $\begin{array}{l}\text { 10,664 traps*night } \\
2,898 \text { traps*night }\end{array}$ & Carmignotto et al. 2014 \\
\hline 24 & yes & $\begin{array}{l}\text { Sherman/Wire traps } \\
\text { Pitfall }\end{array}$ & 1998-1999 & $\begin{array}{l}10,664 \text { traps*night } \\
2,898 \text { pifalls*night }\end{array}$ & Rodrigues et al. 2002 \\
\hline 24 & yes & $\begin{array}{l}\text { Sherman/Wire traps } \\
\text { Pitfall }\end{array}$ & $2003 ; 2008$ & $\begin{array}{l}\text { 5,396 traps*night } \\
5,300 \text { pifalls*night }\end{array}$ & Carmignotto \& Aires 2011 \\
\hline 29 & no & $\begin{array}{l}\text { Sherman/Wire traps } \\
\text { Pitfall }\end{array}$ & $\begin{array}{l}\text { 1988-1989; } \\
\text { 1998-1999; } 1997\end{array}$ & $\begin{array}{l}\text { not available } \\
\text { not available }\end{array}$ & Schneider 2000 \\
\hline \multicolumn{6}{|l|}{ Bats } \\
\hline 9 & no & Mist net & $2003-2004$ & $2,520 \mathrm{~m} 2 *$ hour & Moreira et al. 2008 \\
\hline 10 & no & Mist net & 2008-2013 & $18,144 \mathrm{~m} 2 *$ hour & This study \\
\hline 16 & yes & Mist net & 1986-1998 & not available & Marinho-Filho et al. 1998 \\
\hline 17 & Both & Mist net & $1983-1984$ & not available & Mares et al. 1989 \\
\hline 22 & yes & Mist net & 1998-1999 & $388,800 \mathrm{~m} 2 *$ hour & Aguiar 2000 \\
\hline 23 & no & Mist net & 2004 & $16,650 \mathrm{~m} 2 *$ hour & $\begin{array}{l}\text { Bezerra \& Marinho-Filho } \\
2010\end{array}$ \\
\hline 24 & yes & Mist net & 1998-1999 & $26,838 \mathrm{~m} 2 *$ hour & Rodrigues et al. 2002 \\
\hline 25 & no & Mist net & 1997; $1998-1999$ & not available & Schneider 2000 \\
\hline \multicolumn{6}{|c|}{ Large mammals } \\
\hline 10 & no & Observations & $2003-2004$ & 80 hours & Moreira et al. 2008 \\
\hline 10 & yes & Observations & $2002-2004$ & not available & Pereira \& Geise 2009 \\
\hline 17 & yes & Observations & $2003 ; 2008$ & not available & Carmignotto \& Aires 2011 \\
\hline 18 & no & Observations & 2008-2009 & $143.51 \mathrm{~km}-320$ hours & Alves et al. 2014 \\
\hline 23 & no & Observations & 2008-2009 & $7,200 \mathrm{~km}$ & Bocchiglieri et al. 2010 \\
\hline 26 & yes & Track stations & 2001-2002 & $\begin{array}{l}1,518 \text { track } \\
\text { stations*night }\end{array}$ & Oliveira et al. 2009 \\
\hline & & Census & & $309 \mathrm{~km}-207$ hours & \\
\hline 29 & Both & Observations & 1983-1984 & not available & Mares et al. 1989 \\
\hline 32 & yes & Observations & 1986-1998 & not available & Marinho-Filho et al. 1998 \\
\hline 33 & no & $\begin{array}{l}\text { Observations } \\
\text { Camera trap }\end{array}$ & 2008-2013 & $\begin{array}{l}\text { not available } \\
14,508 \text { traps.hour }\end{array}$ & This study \\
\hline 38 & no & Observations & $1999-2000$ & not available & Brito et al. 2001 \\
\hline 39 & no & Observations & $\begin{array}{l}\text { 1988-1989; 1998- } \\
1999 ; 1997\end{array}$ & not available & Schneider 2000 \\
\hline 37 & yes & Observations/Census & 1994-1999 & not available & Rodrigues et al. 2002 \\
\hline \multicolumn{6}{|c|}{ All mammals } \\
\hline 24 & no & & $2003-2004$ & & Moreira et al. 2008 \\
\hline 58 & yes & & $2002-2004$ & & Pereira \& Geise 2009 \\
\hline 63 & no & & 2008-2013 & & This study \\
\hline 66 & yes & & 1986-1998 & & Marinho-Filho et al. 1998 \\
\hline 85 & yes & & 1994-1999 & & Rodrigues et al. 2002 \\
\hline 86 & Both & & $1983-1984$ & & Mares et al. 1989 \\
\hline 93 & no & & 1997; 1998-1999 & & Schneider 2000 \\
\hline
\end{tabular}

occurring in several Brazilian states, there are few localities in the Brazilian cerrado with formal records in the literature (Oprea et al. 2009), and the species was recorded only in northeastern Goiás (Zortéa \& Alho 2008, Bezerra \& MarinhoFilho 2010, Peracchi et al. 2010). The present record of A. caudifer indicates this species presents a wider distribution across the cerrado. The small bat species richness verified at Serra do Facão may have been caused by a number of causes as well as their combination. 1) We used only mist nets to sample bats and no bat detectors that help to find and identify species that fly high above the canopy of forests and are not easily captured with nets. 2) Bat sampling was conducted in the period between 
18:00 and 24:00 h, and consequently; 3 ) not all bat activity periods were covered and not all areas were explored as well as collection did not take place in all field trips. Thus, the assemblage of bats in Serra do Facão is clearly underestimated and further studies remain be done.

Large mammals - We recorded 33 large mammals species (Table 1, Supplement 4), a richness higher than the sum of richness found in three Protected Areas in Brasília $(n=25)$ (Juarez 2008). Other studies also carried out in other cerrado regions, including Protected Areas (Marinho-Filho et al. 1998, Schneider 2000, Brito et al. 2001, Rodrigues et al. 2002, Moreira et al. 2008, Oliveira et al. 2009, Bocchiglieri et al. 2010, Carmignotto \& Aires 2011, Alves et al. 2014), recorded 10 to 39 species of large mammals (Table 2). However, any comparison on large mammal richness between areas is limited because there is not a standard methodology used in different studies and the sampling efforts performed for this group in different studies are also very different. Indeed, most large mammals checklists are based on opportunistic data.

Eigth species of larger mammals surveyed are threatened with extinction (MMA 2014): Priodontes maximus, Mymercophaga tridactyla, Chrysocyon brachyurus, Lycalopex vetulus, Leopardus tigrinus, L. wiedii, Puma concolor, and P. yagouaroundi. The giant armadillo, Priodontes maximus, occurs in nearly all Brazilian biomes (Medri et al. 2010). This species, as well as their characteristic burrows, were found in both open and forest areas by direct observation and camera trapping. The fact that this species is considered extinct in various localities of southern Brazil (Marinho-Filho \& Medri 2008) and is currently declining in other Brazilian regions, reinforces the importance of Serra do Facão for the conservation of its wild populations. Another threatened species found was the giant anteater, Mymercophaga tridactyla, which originally occurred in all Brazilian biomes, but is currently considered extinct in eastern states of Rio de Janeiro and Espírito Santo, and its populations are declining in southern, southeastern and northeastern Brazil (Medri \& Mourão 2008). In the present study, the giant anteater was the most frequently recorded species among large mammals, using both open and forest areas - where most records were made.

The maned wolf, Chrysocyon brachyurus, a species associated with central Brazilian cerrados (Cheida \& Santos 2010) was one of the rarest species in the present study, and the few records were obtained in open vegetation areas. Furthermore, we recorded the occurrence of some felines threatened with extinction. The margay, Leopardus wiedii, was spotted only in forest environments. Puma concolor, another feline threatened with extinction was the largest predator, with few photo records in the region. We did not detect jaguar, Panthera onca, which could explain the considerable abundance of mesopredators, such as L. wiedii in the area. The oncilla, Leopardus tigrinus, was one of the rarest species among larger mammals and this may be explained by the relatively high frequency of $L$. pardalis, one of the largest predators found, and capable of excluding smaller spotted cats in areas where it is dominant (Oliveira 2004).

Despite the fact that Serra do Facão region has been altered for centuries by several kinds of natural resources exploitation that resulted in a quite fragmented landscape, and the area that we sampled is not included in or near to any protected area, the present study reveals that it still shelters a mammalian fauna corresponding to at least $25 \%$ of the total mammalian fauna of the whole cerrado biome. This richness, in addition to the presence of rare and threatened species, reinforces the importance of natural remnants of cerrado for the conservation of regional mammalian fauna. It also calls attention for the importance of enforcing the protection of natural areas that may be affected by many large infrastructure projects.

\section{Acknowledgments}

We are grateful to Serra do Facão Energia S.A. for financial and logistic support and to Fundação Pró-Natureza for logistic and administrative support; to CAPES for the fellowships to LPG, CRR and JMF; to CNPq for fellowship and financial support to JMF; to all those who helped in the fieldwork; to Danielle Palhares for translating the text into English; to Pedro de Podestá for the map and edition of the pictures; to Alexandra Bezerra, Raquel Ribeiro and Alexandre Portella for help with species identification.

\section{References}

AGUIAR, L.M.S. 2000. Comunidades de morcegos do Cerrado no Brasil central. Tese de Doutorado, Universidade de Brasília.

ALHO, C.J. 2011. Environmental effects of hydropower reservoirs on wild mammals and freshwater turtles in Amazonia: a review. Oecologia Australis. 15 (3): 593-604, http://dx.doi.org/10.4257/ oeco.2011.1503.11

ALVES, G.B., MARÇAL JÚNIOR, O. \& BRITES, V.L.C. 2014. Mamíferos de médio e grande porte de um fragmento de cerrado na região do Triângulo Mineiro, sudeste do Brasil. Bioscience Journal. 30 (3): 863-873.

ANA. 2007. Caderno de Recursos hídricos 3. Agência Nacional das Águas. Brasília - DF

ANDRIOlO, A., PIOVEZAN, U., COSTA, M.J., TORRES, H.A., VOGLIOTTI, A., ZERBINI, A.N. \& DUARTE, J. 2013. Severe population decline of marsh deer, Blastocerus dichotomus (Cetartiodactyla: Cervidae), a threatened species, caused by flooding related to a hydroelectric power plant. Zoologia (Curitiba). 30 (6): 630-638.

BECKER, M. \& DALPONTE, J.C. 1991. Rastros de mamíferos silvestres brasileiros: um guia de campo. Editora Universidade de Brasília, p.180.

BENNETT, A.F. 1990. Habitat corridors and the conservation of small mammals in a fragmented forest environment. Landscape Ecology. 4 (2-3): 109-122, http://dx.doi.org/10.1007/BF00132855

BEZERRA, A.M. \& MARINHO-FILHO, J. 2010. Bats of the Paranã River Valley, Tocantins and Goiás states, Central Brazil. Zootaxa. 2725: 41-56.

BOCCHIGLIERI, A., MENDONÇA, A.F. \& HENRIQUES, R.P.B. 2010. Composição e diversidade de mamíferos de médio e grande porte no Cerrado do Brasil central. Biota Neotropica. 10 (3): 169-176. http:// www.biotaneotropica.org.br/v11n1/en/abstract?article + bn03911012011 (20/06/2014), http://dx.doi.org/10.1590/S1676-06032010000300019

BONVICINO, C.R., LINDBERGH, S.M., BARROS, M. \& BEZERRA, A.M. 2012. The eastern boundary of the Brazilian Cerrado: a hotspot region. Zool Stud. 51: 1207-1218.

BONVICINO, C.R., OLIVEIRA, J.D. \& D'ANDREA, P.S. 2008. Guia dos roedores do Brasil, com chaves para gêneros baseadas em caracteres externos. Centro Pan-Americano de Febre AftosaOPAS/OMS, Rio de Janeiro. p.120.

BORGES, P.L. \& TOMÁS, W. 2004. Guia de rastros e outros vestígios de mamíferos do Pantanal. Embrapa Pantanal, Corumbá, MT, p. 148 .

BRITO, B., TROVATI, R.G. \& PRADA, M. 2001. Levantamento dos mamíferos terrestres de médio e grande portes na área de influência da UHE Luís Eduardo Magalhães, região central do Tocantins. Humanitas. 3: 7-20. 
CÁCERES, N.C., GRAIPEL, M.E. \& MONTEIRO-FILHO, E.L.A. 2010. Técnicas de observação e amostragem de marsupiais. In Técnicas de estudos aplicadas aos mamíferos silvestres brasileiros (N.R. Reis, A.L. Peracchi, B.K. Rossaneis \& M.N. Fregonezi eds). Technical Books Editora, Rio de Janeiro, p.21-36.

CARDOSO, M.R.D., MARCUZZO, F.F.N. \& BARROS, J.R. 2015. Classificação Climática de Köppen-Geiger para o Estado de Goiás e o Distrito Federal. ACTA GEOGRÁFICA. 8 (16): 40-55.

CARMIGNOTTO, A.P. \& AIRES, C.C. 2011. Mamíferos não voadores (Mammalia) da Estação Ecológica Serra Geral do Tocantins. Biota Neotropica. 11 (1): 307-322. http://www.biotaneotropica.org. br/v11n1/en/abstract?article + bn03911012011 (20/06/2014)

CARMignotTO, A.P., DE VIVO, M. \& LANGGUTH, A. 2012. Mammals of the Cerrado and Caatinga: distribution patterns of the tropical open biomes of Central South America. Bones, clones and biomes. The history and geography of recent Neotropical mammals (BD Patterson and LP Costa, eds.). University of Chicago Press, Chicago, Illinois. p.307-350.

CARMIGNOTTO, A.P. \& MONFORT, T. 2006. Taxonomy and distribution of the Brazilian species of Thylamys (Didelphimorphia: Didelphidae)/La taxonomie et la distribution des espèces brésiliennes du genre Thylamys (Didelphimorphia: Didelphidae). Mammalia. 70 (1/2): 126-144.

CARVALHO JR, O. \& LUZ, N. 2008. Pegadas: Série Boas Práticas, v. 3. EDUFPA, Belém, 64p.

CHAUL, N.N.F. 1997. Caminhos de Goiás: da construção da decadência aos limites da modernidade. UFG, Goiânia.

CHEIDA, C.C. \& SANTOS, L.B. 2010. Ordem Carnvora. In Mamíferos do Brasil - Guia de Identificação (N.R. Reis, A.L. Peracchi, M.N. Fregonezi \& B.K. Rossaneis eds). Thechnical Books, Rio de Janeiro, p. $463-492$.

COLWELL, R.K. 2013. "EstimateS: Statistical estimation of species richness and shared species from samples." User's Guide and application available online at http://purl.oclc.org/estimates.

COSSON, J., RINGUET, S., CLAESSENS, O., DE MASSARY, J., DALECKY, A., VILLIERS, J., GRANJON, L. \& PONS, J. 1999. Ecological changes in recent land-bridge islands in French Guiana, with emphasis on vertebrate communities. Biological conservation. 91 (2): 213-222.

COSTA, L.P., LEITE, Y.L.R., MENDES, S.L. \& DITCHFIELD, A.B. 2005. Conservação de mamíferos no Brasil. Megadiversidade. 1: 103-112.

DE ANGELO, C., DI BLANCO, Y., PAVIOLO, A. \& PROYUNGAS, F. 2008. Guía de huellas de los mamíferos de Misiones y otras áreas del Subtrópico de Argentina. Ed. del Subtrópico, Tucumán, Argentia, p.120.

EISENBERG, J.F. \& REDFORD, K.H. 1999. Mammals of the Neotropics - The Central Neotropics: Ecuador, Peru, Bolivia, Brazil. Chicago, Univ. Chicago Press, Chicago, p.609.

EMMONS, L. \& FEER, F. 1997. Neotropical rainforest mammals: a field guide.

FOURNIER-CHAMBRILLON, C., FOURNIER, P., GAILLARD, J.-M., GENTY, C., HANSEN, E. \& VIÉ, J.-C. 2000. Mammal trap efficiency during the fragmentation by flooding of a neotropical rain forest in French Guiana. Journal of Tropical Ecology. 16 (06): 841-851.

GARDNER, A.L. 2008. Mammals of South America, volume 1: marsupials, xenarthrans, shrews, and bats. University of Chicago Press, Chicago, p.669.

JUAREZ, K.M. 2008. Mamíferos de Médio e Grande Porte nas Unidades de Conservação do Distrito Federal. Tese de Doutorado, Universidade de Brasília.

KLINK, C.A. \& MACHADO, R.B. 2005. A conservação do Cerrado brasileiro. Megadiversidade. 1 (1): 147-155.

LEMOS DE SÁ, R.M. 1995. Effects of the Samuel Hydroelectric dam on mammal and bird communities in a heterogeneous Amazonian lowland forest.

LENZA, E., PINTO, J.R.R., PINTO, A., MARACAHIPES, L. \& BRUZIGUESSI, E. 2011. Comparação da vegetação arbustivo-arbórea de uma área de cerrado rupestre na Chapada dos Veadeiros, Goiás, e áreas de cerrado sentido restrito do Bioma Cerrado. Revista Brasileira de Botânica. 34 (3): 247-259.

MAMEDE, S.B. \& ALHO, C.J.R. 2006. Impressões do Cerrado \& Pantanal: subsídios para a observação de mamíferos silvestres não voadores. Editora UNIDERP, Campo Grande, MS, p.208.

MARES, M.A., BRAUN, J.K. \& GETTINGER, D. 1989. Observations on the distribution and ecology of the mammals of the cerrado grasslands of central Brazil. Annals of Carnegie Museum. 58: $1-60$.

MARES, M.A. \& ERNEST, K.A. 1995. Population and community ecology of small mammals in a gallery forest of central Brazil. Journal of Mammalogy. 76 (3): 750-768.

MARINHO-FILHO, J. \& MEDRI, I.M. 2008. Priodontes maximus (Kerr, 1792). In Livro Vermelho da fauna brasileira ameaçada de extinção (A.B.M. Machado, G.M. Drummond \& A.P. Paglia eds). MMA, Brasília, p.707-709.

MARINHO-FILHO, J., RODRIGUES, F.H.G., GUIMARÃES, M.M. \& REIS, M.L. 1998. Mamíferos da Estação Ecológica de Águas Emendadas, Planaltina, DF. In Vertebrados da Estação Ecológica de Águas Emendadas (J. Marinho-Filho, F.H.G. Rodrigues \& M.M. Guimarães eds). Secretaria de Meio Ambiente, Ciência e Tecnologia do Distrito Federal, Brasília-DF, p.34-63.

MARINHO-FILHO, J., RODRIGUES, F.H.G. \& JUAREZ, K.M. 2002. The cerrado mammals: diversity, ecology, and natural history. In The Cerrado of Brazil. (P.S. Oliveira \& R.J. Marquis eds). Editora Columbia University, Nova Iorque, USA, p.267-284.

MEDRI, I.M. \& MOURÃO, G. 2008. Mymercophaga tridactyla Linnaeus, 1758. In Livro vermelho da fauna brasileira ameaçada de extinção (G.M.D. Machado, G.M. Drummond \& P.A. P. eds). MMA, Brasília, DF, p.711-713.

MEDRI, I.M., SAMPAIO, M.B. \& TOMAS, W.M. 2010. Ordem Cingulata. In Mamíferos do Brasil - Guia de Identificação (N.R. Reis, A.L. Peracchi, M.N. Fregonezi \& B.K. Rossaneis eds). Thechnical Books, Rio de Janeiro, p.79-90.

MENGAK, M.T. \& GUYNN JR, D.C. 1987. Pitfalls and snap traps for sampling small mammals and herpetofauna. American Midland Naturalist. 284-288.

MMA. 2014. Lista Nacional Ofical De Espécies Da Fauna Ameaçadas De Extinção. PORTARIA No- 444, DE 17 DE DEZEMBRO DE 2014.

MONTEIRO-FILHO, E.L.A. \& GRAIPEL, M.E. 2006. Captura e Marcação. In Os Marsupiais do Brasil: biologia, ecologia e evolução (N.C. Cáceres \& E.L.A. Monteiro-Filho eds). Universidade Federal do Mato Grosso do Sul, Campo Grande, p.17-27.

MOREIRA, J., MANDUCA, E., GONÇALVES, P., STUMPP, R., PINTO, C. \& LESSA, G. 2008. Mammals, Volta Grande Environmental Unity, Triângulo Mineiro, states of Minas Gerais and São Paulo, Southeastern Brazil. Check list. 4: 349-357.

MYERS, N., MITTERMEIER, R.A., MITTERMEIER, C.G., FONSECA, G.A.B. \& KENT, J. 2000. Biodiiversity hotspots for conservation priorities. Nature. 403: 845-853.

OLIVEIRA-FILHO, A.T. \& RATTER, J.A. 2002. Vegetation physiognomies and woody flora of the Cerrado biome. In The Cerrado of Brazil. (P.S. Oliveira \& R.J. Marquis eds). Editora Columbia University, Nova Iorque, USA, p.91-119.

OLIVEIRA, T.D. \& CASSARO, K. 1999. Guia de identificação dos felinos brasileiros. São Paulo: Sociedade dos Zoológicos do Brasil.

OLIVEIRA, T.G. 2004. The oncilla in Amazonia: unraveling a myth. Cat News. 41: 29-32.

OLIVEIRA, V.B., CÂMARA, E.M.V.C. \& OLIVEIRA, L.C. 2009. Composiçao e caracterizaçao da mastofauna de médio e grande porte do Parque Nacional da Serra do Cipó, Minas Gerais, Brasil. Mastozoología Neotropical. 16: 355-364. http://www.scielo.org.ar/scielo.php? script $=$ sci_arttext\&pid $=$ S0327-93832009000200008\&nrm $=$ iso

OPREA, M., AGUliAR, L.M. \& WILSON, D.E. 2009. Anoura caudifer (Chiroptera: Phyllostomidae). Mammalian Species. 1-8.

PAGLIA, A.P., DA FONSECA, G.A., RYLANDS, A.B., HERRMANN, G., AGUIAR, L.M., CHIARELlO, A.G., LEITE, Y.L., 
COSTA, L.P., SICILIANO, S. \& KIERULFF, M.C.M. 2012. Lista Anotada dos Mamíferos do Brasil $2^{\mathrm{a}}$ Edição Annotated Checklist of Brazilian Mammals. Conservation International, Arlington, VA.

PASSAMANI, M. \& CERBONCINI, R.A.S. 2013. The effects of the creation of a hydroelectric dam on small mammals' communities in central Brazil. Neotropical Biology and Conservation. 8 (1): 9-16.

PERACCHI, A.L., GALLO, P.H., DIAS, D., LIMA, I.P. \& REIS, N.R. 2010. Chiroptera. In Mamíferos do Brasil - Guia de identificação (N.R. Reis, A.L. Peracchi, M.N. Fregonezi \& B.K. Rossaneis eds). Technical Books, Rio de Janeiro, p.293-462.

PEREIRA, L.G. \& GEISE, L. 2009. Non-flying mammals of Chapada Diamantina (Bahia, Brazil). Biota Neotropica. 9 (3): 185-196. http:// www.biotaneotropica.org.br/v9n3/en/abstract?article + bn03709032009 (20/06/2014), http://dx.doi.org/10.1590/S1676-06032009000300019

REIS, N.R., FREGONEZI, M.N., PERACCHI, A.L. \& SHIBATTA, O.A. 2013. Morcegos do Brasil: Guia de campo. Londrina, p.253.

ROCHA, C.R. 2011. Dinâmica populacional de roedores em um Cerrado do Brasil central. Thesis, Universidade de Brasília.

RODRIGUES, F.H.G., SILVEIRA, L., JÁCOMO, A.T.A., CARMIGNOTTO, A.P., BEZERRA, A.M.R., COELHO, D.C., GARBOGINI, H., PAGNOZZI, J. \& HASS, A. 2002. Composição e caracterização da fauna de mamíferos do Parque Nacional das Emas, Goiás, Brasil. Revista Brasileira De Zoologia. 19: 589-600, http://dx.doi.org/10.1590/S0101-81752002000200015

SANTOS FILHO, M., SILVA, D.J. \& SANAIOTTI, T.M. 2008. Variação sazonal na riqueza e na abundância de pequenos mamíferos, na estrutura da floresta e na disponibilidade de artrópodes em fragmentos florestais no Mato Grosso, Brasil. Biota Neotropica. 8: 115-121, http://dx.doi.org/10.1590/S1676-06032008000100014

SCHNEIDER, M. 2000. Mastofauna. In Fauna silvestre da região do rio Manso - MT (C.J.R. Alho, P.N. Conceição, R. Constantino, T. Schlemmermeyer, C. Strussmann, L.A.S. Vasconcellos, D.M.M. Oliveira \& M. Schneider eds). IBAMA, Brasília, DF, p.217-238.

SIKES, R.S. \& GANNON, W.L. 2011. Guidelines of the American Society of Mammalogists for the use of wild mammals in research. Journal of Mammalogy. 92 (1): 235-253.

STRAUBE, F.C. \& BIANCONI, G.V. 2002. Sobre a grandeza e a unidade utilizada para estimar esforço de captura com utilização de redes-de-neblina. Chiroptera Neotropical. 8 (1-2): 150-152.

TROLlE, M., BISSARO, M.C. \& PRADO, H.M. 2007. Mammal survey at a ranch of the Brazilian Cerrado. In Vertebrate Conservation and Biodiversity eds). Springer, p.379-385.

VIZOTTO, L. \& TADDEI, V. 1973. Chave para determinação de quirópteros brasileiros. Boletim de Ciências. 1 (1): 1-72.

WEKSLER, M. \& BONVICINO, C.R. 2005. Taxonomy of pigmy rice rats genus Oligoryzomys Bangs, 1900 (Rodentia, Sigmodontinae) of the Brazilian Cerrado, with the description of two new species. Arquivos do Museu Nacional, Rio de Janeiro. 63 (1): 113-130.

WHITMORE, T.C. \& SAYER, J.A. 1992. Tropical deforestation and species extinction. Chapman \& Hall, London.

ZAR, J.H. 1999. Biostatistical analysis. Pearson Education India, New Jersey, p.663.

ZORTÉA, M. \& ALHO, C.J. 2008. Bat diversity of a Cerrado habitat in central Brazil. Biodiversity and Conservation. 17 (4): 791-805.

Received 06/05/2015

Revised 23/07/2015

Accepted 10/09/2015 